\title{
Clostridium difficile cdt DNA Measurement
}

National Cancer Institute

\section{Source}

National Cancer Institute. Clostridium difficile cdt DNA Measurement. NCI Thesaurus.

Code C150866.

The determination of the amount of cdt DNA produced by Clostridium difficile present in a sample. 